\title{
THE ASSOCIATION BETWEEN CONTACT HISTORY, OCCUPANCY DENSITY, AND THE RISK OF LUNG TUBERCULOSIS IN ADULT AGED 15-49 YEARS IN MANDAILING NATAL, NORTH SUMATERA
}

\author{
Nourma Junita, Erna Mutiara, Taufik Ashar \\ Masters Program in Public Health, Faculty of Public Health, \\ Universitas Sumatera Utara
}

\begin{abstract}
Background: Tuberculosis (TB) is the leading cause of death in the world. An estimated $1 / 3$ of the world's population has been infected with Tuberculosis bacteria. It is estimated that in 2020 there will be 56 million people infected. In 2015 there are 10.4 million new cases of Tuberculosis and as many as 1.4 million people die from Tuberculosis. This study aimed to analyze the association between contact history, dwelling density, and the risk of lung tuberculosis in adult aged 15-49 years in Mandailing Natal District, North Sumatera.

Subjects and Method: This was an analytical observational study with the case-control design. The study was conducted at Siabu Health Center, Mandailing Natal District, North Sumatera. The study subjects were 98 people aged 15-49 years, consisting of 49 people suffering from pulmonary tuberculosis (cases) and 49 people not suffering from pulmonary tuberculosis (control) were selected using fixed disease sampling. The dependent variable was the incidence of pulmonary TB. The independent variables were a history of contact with patients with pulmonary TB and occupancy density. Data were collected using questionnaires and analyzed using a multiple logistic regression.

Results: History of contact with pulmonary TB patients $(\mathrm{OR}=10.79 ; \mathrm{p}=0.001)$ and occupancy density $(\mathrm{OR}=8.06 ; \mathrm{p}=0.0001)$ increased the risk of pulmonary TB incidence.

Conclusion: Contact history and occupancy density are risk factors for pulmonary tuberculosis.
\end{abstract}

Keywords: lung tuberculosis, contact history, occupancy density

Correspondence:

Nourma Junita. Masters Program in Public Health, Faculty of Public Health, Universitas Sumatera Utara. Email: nita.latansa18@gmail.com.

Mobile: 082165065582. 